\title{
SAFETY CLIMATE SURVEY AMONG EMPLOYEES IN A FEMININE CARE PRODUCTS MANUFACTURING COMPANY
}

\author{
Listia Annisa, Fatma Lestari* \\ Occupational Health and Safety Department, Faculty of Public Health, Universitas Indonesia. Kampus Baru \\ UI Depok, West Java 16424, Indonesia.
}

\begin{abstract}
Manufacturing and construction companies are significant contributors to most accidents in Indonesia. Accident frequency rate (AFR) can be reduced by adopting an appropriate management system, technical approach, and safety culture at the workplace. Employees' perception of Work Safety culture is the key to success in minimizing AFR. A survey of employees' perception of safety can identify their reality concerning the Safety Climate at their workplace. The study aimed to observe Safety Climate through a survey of employees' perception on the dimensions of management commitment, safety communication, safety rules and procedures, supportive environment, personal safety involvement and needs, and safety training. The study discusses possible ways to improve the safety climate in their organization and provides feedback to maintain and improve it. A mixed-methods descriptive design was used for this study. The sample size was determined using the Slovin formula and the sample selection using the Proportionate Stratified Random Sampling method. The survey was conducted on 156 employees using a questionnaire model with a personal approach to all levels of employees in a feminine care products manufacturing company. The survey result was analyzed quantitatively through assessments on questionnaires and qualitatively through employees' comments. The study found employees' perception of safety climate to be at a reasonable level. The management commitment dimension in this study has the best assessment result. The analysis results showed that the active role of the leadership, strong safety values to build employee interaction, employee involvement and investment in training programs for employees were critical keys to the successful implementation of Occupational Safety.
\end{abstract}

Keywords: manufacturing company employees, occupational safety, perception of safety, safety climate

\begin{abstract}
ABSTRAK
Perusahaan manufaktur dan konstruksi berkontribusi pada sejumlah besar kecelakaan di Indonesia. Fluktuasi angka kecelakaan tidak hanya ditentukan oleh penerapan sistem manajemen dan pendekatan keteknikan, tetapi juga harus memperhatikan aspek budaya keselamatan di tempat kerja. Persepsi karyawan terhadap penerapan Keselamatan Kerja merupakan salah satu kunci keberhasilan dalam meminimalisir angka kecelakaan. Survei persepsi keselamatan di antara karyawan mengidentifikasi realitas mereka tentang Iklim Keselamatan di tempat kerja. Studi ini bertujuan untuk mengamati Iklim Keselamatan melalui survei persepsi karyawan pada dimensi komitmen manajemen, komunikasi keselamatan, aturan dan prosedur keselamatan, lingkungan yang mendukung, keterlibatan dan kebutuhan keselamatan pribadi, dan pelatihan keselamatan. Studi ini memberikan pengetahuan melalui ulasan bagaimana membuat iklim keselamatan menjadi baik dalam organisasi tersebut, serta untuk memberikan umpan balik tentang bagaimana hal itu dapat dipertahankan dan juga ditingkatkan. Desain metode campuran deskriptif digunakan dalam studi ini. Besar sampel ditentukan menggunakan rumus Slovin dan pemilihan sampel menggunakan metode Proportionate Stratified Random Sampling. Survey dilakukan pada 156 karyawan menggunakan model kuesioner dengan pendekatan personal kepada seluruh level karyawan di sebuah perusahaan manufaktur produk perawatan wanita. Hasil survey dianalisis secara kuantitatif melalui penilaian pada kuesioner dan kualitatif melalui komentar/masukan para karyawan. Hasil penelitian menunjukkan bahwa persepsi keselamatan karyawan berada pada tingkat yang baik. Dimensi Management Commitment pada penelitian ini mendapatkan penilaian paling baik. Hasil analisis menunjukkan bahwa peran aktif pimpinan, nilai keselamatan yang kuat untuk membangun interaksi karyawan, dan investasi dalam program pelatihan bagi karyawan merupakan kunci penting keberhasilan penerapan Keselamatan Kerja.
\end{abstract}

Kata kunci: iklim keselamatan, karyawan perusahaan manufaktur, keselamatan kerja, persepsi keselamatan

Correspondece Address: Fatma Lestari, Occupational Health and Safety Department, Faculty of Public Health, Universitas Indonesia. Kampus Baru UI Depok, West Java 16424, Indonesia, E-mail: fatma@ui.ac.id 


\section{Introduction}

Indonesian Population Census data by Badan Pusat Statistik Indonesia (Central Agency on Statistics) records that Women of Reproductive Age (WRA) aged 15-49 years ${ }^{1}$ in Indonesia increased 14\% within 10 (ten) years (2010-2020). ${ }^{2,3}$ Along with the growth of the WRA population, the usage of Indonesian sanitary napkins is still minimal, namely 2-3 pieces per day. In fact, sanitary napkins in developed countries have reached 5-6 pieces per day. Therefore, the sanitary napkin industry can still grow double. ${ }^{4}$ In general, the sanitary napkins industry has not yet applied fully automated technology to produce products. Mainly the technology combines machine and labor. Consequently, feminine care products manufacturing operations are always accompanied by factors that potentially risk causing work-related accidents and occupational diseases.

The manufacturing and construction sectors are two significant contributors to the Accident Frequency Rate (AFR) in Indonesia. ${ }^{5,6}$ Within 18 years, the number of work-related accident cases in Indonesia based on BPJS Ketenagakerjaan (Social Security Agency for Employment) data was $1,890,844$ cases $^{5,7}$ with an average work accident of $4 \%$ from year to year, while the fatality rate was $2 \%$ of the total work-related accidents in the period 2001-2018. ${ }^{7,8}$

Work accidents reported to BPJS Ketenagakerjaan are dominated by accidents occurring within factory sites among employees in the productive age group with lower competence levels. ${ }^{5}$

To minimize occupational hazards at the workplace, the Indonesian Government has issued Government Regulation Number 50 of 2012 concerning the Occupational Health and Safety Management System (OHSMS). A study reported that well-directed implementation of OHSMS could reduce work accident rates significantly. ${ }^{9}$ In addition, the mutual involvement of the management and employees is key to good OHSMS in a company. ${ }^{10}$ However, OHSMS would not be well in place if it is not framed within a positive safety culture. ${ }^{11}$

The Safety Culture is the total sum of the individuals' values, attitudes, perceptions, and competencies in an organization. Safety Culture can also be thought of as the result of the interactions between the personal, occupational, and organizational factors. ${ }^{12}$ Safety Culture is shaped through complex processes influenced by leadership commitment, employees' values, employees' perception of work safety (safety climate), employees' involvement, prevailing policies/procedures, and responsibility/accountability. Safety Climate refers to the reality in an organization, including occupational, organizational, and perception of safety system factors. ${ }^{13}$ This reality reflects an actual safety climate from which indicators of safety culture can be identified. The industry is obliged to have a safety climate that performs well to establish a superior safety culture. In destiny, it will prevent work-related accidents. This study aimed to observe the Safety 
Climate of a multinational feminine care products manufacturing company through a survey of employees' perceptions.

\section{Method}

This study used an instrument of a safety climate framework constructed by Zou and Sunindijo. ${ }^{14}$ The questionnaire has previously been validated and used in several studies in the construction sector. ${ }^{15,16,17}$ The Safety Climate Survey contained 58 statements from each dimension of Safety Climate, namely: Management Commitment, Communication, Rules and Procedures, Work Environment, Employees' Involvement, Individual Safety Needs, and Training. A face-toface method was adopted to maximize responses and to obtain results that reflected the actual workplace situation. The survey was composed of two groups of questions. The first part was intended to gather demographic data, including respondents' gender, age, education, employment status, and length of service at the manufacturing company. The second part was to assess safety climate based on the 58 statements adapted from the previous study, which encompassed the following six dimensions: Management Commitment (9 items), Safety Communication (9 items), Safety Rules and Procedures (6 items), Supportive Environment (15 items), Personal Safety Involvement and Needs (14 items), and Safety Training (5 items).

For each dimension of Safety Climate, there are several positive and negative statements so that respondents can provide honest responses to each statement given. Every statement had to be responded to by selecting a number from 1 to 6 according to the Likert Scale, where $1=$ Strongly Disagree, 2 = Disagree, $3=$ Slightly Disagree, $4=$ Slightly Agree, $5=$ Agree, and $6=$ Strongly Agree. The collected results are processed using Microsoft Excel to produce data in the Mean on each questionnaire statement and Safety Climate dimension. A frequency distribution is also displayed to obtain more detailed information on how each employee responded to each research questionnaire's statements. The result is presented in the positive statement, and the score has been adjusted. The final result was a Total Mean: the higher the Total Mean, the better the Safety Climate.

The survey was conducted at a multinational feminine products manufacturing company based in Bekasi Regency, West Java, Indonesia. The sample size was calculated using Slovin's formula with a $5 \%$ margin of error ${ }^{18}$ from a population (N) of 257 employees. The resulting sample size was 156 (60\% of the population of employees). Samples were selected through the Proportionate Stratified Random Sampling method ${ }^{19}$, where the employee population is grouped into strata according to the position and department. In each population group $(\mathrm{N}), 60 \%$ of the sample (n) are selected randomly until it reaches the number of the minimum sample is 156 employees. This study is to reach out to all the departments and levels at the study site.Data on employees at managerial and staff levels were taken during regular working hours, whereas 
workers' level data were collected according to their shifts ( 3 shifts). The average time needed to interview each participant was 30 minutes. The interviews were completed within 3 (three) weeks, taking into account the working hours of those working in shifts.

The study was conducted using a mixed-methods descriptive design study. Questionnaire data and respondents' comments were analyzed using mixed methods (quantitative and qualitative methods). The analysis results were presented descriptively. This research had received ethical approval from The Research and Community Engagement Ethical Committee, Faculty of Public Health, Universitas Indonesia, Number: Ket- 434/UN2.F10.D11/PPM.00.02/2020.

\section{Results}

\section{Demographic}

The sample size was determined using Slovin's formula (margin of error $=5 \%$ ), which yielded a minimum sample size of 156 employees for the study. Samples were selected by using the Proportionate Stratified Random Sampling method, of which results are shown below.

Table 1. Research Sample.

\begin{tabular}{|c|c|c|c|c|c|}
\hline \multirow{2}{*}{ Department } & \multicolumn{3}{|c|}{ Number of Samples } & \multirow{2}{*}{ Total } & \multirow{2}{*}{$\begin{array}{c}\text { Percentage } \\
(\%)\end{array}$} \\
\hline & Management & Staff & Worker & & \\
\hline Plant Management & 1 & 0 & 0 & 1 & 0.6 \\
\hline Production & 1 & 9 & 83 & 93 & 59.6 \\
\hline Logistic and Procurement & 2 & 8 & 20 & 30 & 19.2 \\
\hline Quality & 1 & 3 & 9 & 13 & 8.3 \\
\hline Engineering & 1 & 4 & 6 & 11 & 7.0 \\
\hline Environment, Health \& Safety & 0 & 1 & 0 & 1 & 0.6 \\
\hline Operational Excellence & 0 & 1 & 0 & 1 & 0.6 \\
\hline Human Resources & 1 & 4 & 0 & 5 & 3.2 \\
\hline Finance & 1 & 0 & 0 & 1 & 0.6 \\
\hline Total & 8 & 30 & 118 & 156 & 100 \\
\hline
\end{tabular}

Note:

- Managerial and Staff Level employees were those working in the office area.

- Workers were those in non-office areas.

All the samples selected gave their consent to follow the survey, and 156 responses were collected. Data were gathered through face-to-face interviews. The 156 respondents were willing to respond to all the questions and statements altogether, and 68 added some comments.

Table 2 below show that the majority of the respondents were male (73.7\%). More than half (66\%) of the respondents were within the age range of 21-30 and 41-50, their average age being 35 . The respondents consisted of $67.3 \%$ permanent employees and $32.7 \%$ contract employees. In terms of years of working, the largest group (40\%) was employees working for the company for under one until five years. The average years of working among permanent employees were 14.7 years. In addition, $80.1 \%$ of the total respondents attended High School/Vocational High School education. 
Table 2. Employees' Characteristics.

\begin{tabular}{cccc}
\hline Profile & Classification & $\begin{array}{c}\text { Frequency } \\
(\mathbf{n}=\mathbf{1 5 6})\end{array}$ & $\begin{array}{c}\text { Percentage } \\
(\mathbf{\%})\end{array}$ \\
\hline \multirow{2}{*}{ Gender } & Male & 115 & 73.7 \\
& Female & 41 & 26.2 \\
& 20 and below & 5 & 3.2 \\
Age (Years) & $21-30$ & 52 & 33.3 \\
& $31-40$ & 42 & 26.9 \\
& $41-50$ & 51 & 32.7 \\
& 51 and above & 6 & 3.8 \\
Education & Average & 35 years & \\
& High School/ & 125 & 80.1 \\
& Vocational High School & 12 & 7.7 \\
Type of Employee & Associate & 19 & 12.2 \\
& Bachelor & 105 & 67.3 \\
& Permanent Employee & 51 & 32.7 \\
& Temporary Employee & 51 & 32.7 \\
& Below 1 & 12 & 7.7 \\
Years of Working & $1-5$ & 19 & 12.2 \\
& $6-10$ & 23 & 14.7 \\
& $11-15$ & 24 & 15.4 \\
& $16-20$ & 27 & 17.3 \\
& 20 and above & Average & 14.7 years
\end{tabular}

\section{Safety Climate Survey Result}

Table 3 presents the Mean values of each dimension of Safety Climate. The Total Mean response value was 4.89 (approximating 'Agree'). The Mean values in each dimension of the Safety Climate ranged from 4.75 to 5.20. These results generally indicated that the Safety Climate on the level 'Agree'.

Table 3. Values of each Safety Climate dimension.

\begin{tabular}{lc}
\hline \multicolumn{1}{c}{ Dimension } & Mean \\
\hline Management Commitment & 5.20 \\
Safety Communication & 4.87 \\
Safety Rules and Procedures & 4.75 \\
Supportive Environment & 4.77 \\
Personal Safety Involvement and Needs & 4.95 \\
Safety Training & 4.78 \\
\hline Total Mean & $\mathbf{4 . 8 9}$ \\
\hline Note: 1 = strongly disagree, 6 = strongly agree &
\end{tabular}




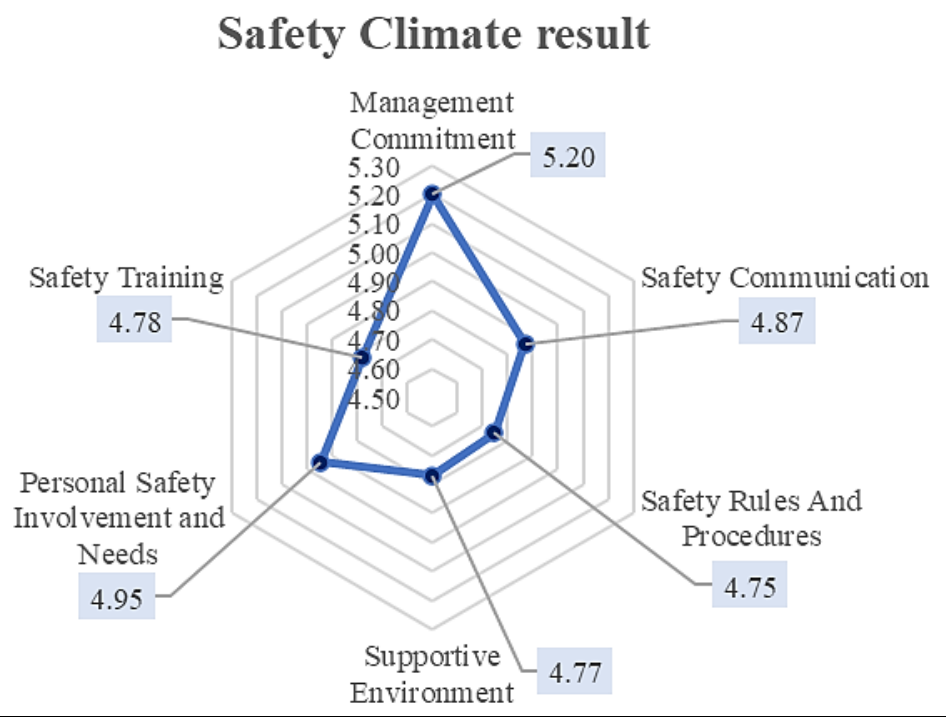

Figure 1. Safety Climate dimension values

\section{Safety Climate Dimension Result}

The following section shall explain the Safety Climate dimensions in more detail in terms of their Mean values of the responses given by the respondents to each statement shows in Table 4.

Table 4. Individual Safety Climate dimension result.

\begin{tabular}{|c|c|c|c|c|c|c|c|c|}
\hline \multirow[b]{2}{*}{ No } & \multirow[b]{2}{*}{ Item } & \multicolumn{6}{|c|}{ Frequency Distribution } & \multirow[b]{2}{*}{ Mean } \\
\hline & & $\begin{array}{c}\text { Strongly } \\
\text { Disagree } \\
\text { (1) }\end{array}$ & $\begin{array}{c}\text { Disagree } \\
(2)\end{array}$ & $\begin{array}{c}\text { Slightly } \\
\text { Disagree } \\
(3)\end{array}$ & $\begin{array}{c}\text { Slightly } \\
\text { Agree } \\
(4)\end{array}$ & $\begin{array}{c}\text { Agree } \\
(5)\end{array}$ & $\begin{array}{c}\text { Strongly } \\
\text { Agree } \\
(6)\end{array}$ & \\
\hline $\mathbf{A}$ & Management Commitment & & & & & & & \\
\hline A1 & $\begin{array}{l}\text { My Plant Manager acts quickly to correct safety } \\
\text { problems. }\end{array}$ & 0 & 1 & 2 & 16 & 86 & 51 & 5.18 \\
\hline A2 & $\begin{array}{l}\text { My Plant Manager consistently implements } \\
\text { corrective actions when told about unsafe behavior } \\
\text { or conditions. }\end{array}$ & 1 & 1 & 3 & 12 & 90 & 49 & 5.15 \\
\hline A3 & My direct Supervisor pays attention to my safety. & 0 & 0 & 3 & 17 & 79 & 57 & 5.22 \\
\hline A4 & $\begin{array}{l}\text { My Plant Manager expresses concern if safety } \\
\text { procedures are not adhered to. }\end{array}$ & 1 & 1 & 2 & 24 & 87 & 41 & 5.04 \\
\hline A5 & $\begin{array}{l}\text { My Plant Manager considers the safety of } \\
\text { employees a top priority. }\end{array}$ & 0 & 0 & 0 & 2 & 69 & 85 & 5.53 \\
\hline A6 & $\begin{array}{l}\text { My Plant Manager considers safety issues } \\
\text { seriously. }\end{array}$ & 0 & 2 & 12 & 8 & 62 & 72 & 5.22 \\
\hline A7 & $\begin{array}{l}\text { My Plant Manager focuses on safety at all times, } \\
\text { not only after accidents have occurred. }\end{array}$ & 0 & 10 & 11 & 12 & 68 & 55 & 4.94 \\
\hline A8 & $\begin{array}{l}\text { My direct Supervisor begins the work only when } \\
\text { working conditions are safe. }\end{array}$ & 0 & 4 & 6 & 12 & 67 & 67 & 5.20 \\
\hline A9 & My direct Supervisor stops work when it is unsafe. & 0 & 0 & 5 & 8 & 73 & 70 & 5.33 \\
\hline & & & & & & & erage & 5.20 \\
\hline $\mathbf{B}$ & Safety Communication & & & & & & & \\
\hline $\mathrm{B} 1$ & Safety communication is effective. & 0 & 2 & 3 & 25 & 102 & 24 & 4.92 \\
\hline B2 & $\begin{array}{l}\text { Safety communication makes me pay attention to } \\
\text { safety. }\end{array}$ & 0 & 0 & 1 & 18 & 101 & 36 & 5.10 \\
\hline B3 & Safety information is always up to date. & 0 & 0 & 2 & 22 & 95 & 37 & 5.07 \\
\hline B4 & I receive a lot of safety information. & 0 & 1 & 11 & 31 & 86 & 27 & 4.81 \\
\hline B5 & $\begin{array}{l}\text { Safety information is always brought to my } \\
\text { attention by my direct Supervisor. }\end{array}$ & 0 & 0 & 5 & 26 & 89 & 36 & 5.00 \\
\hline B6 & My Plant Manager is available for discussion when & 0 & 2 & 20 & 36 & 72 & 26 & 4.64 \\
\hline
\end{tabular}




\begin{tabular}{|c|c|c|c|c|c|c|c|c|}
\hline \multirow[b]{2}{*}{ No } & \multirow[b]{2}{*}{ Item } & \multicolumn{6}{|c|}{ Frequency Distribution } & \multirow[b]{2}{*}{ Mean } \\
\hline & & $\begin{array}{c}\text { Strongly } \\
\text { Disagree } \\
\text { (1) }\end{array}$ & $\begin{array}{c}\text { Disagree } \\
(2)\end{array}$ & $\begin{array}{c}\text { Slightly } \\
\text { Disagree } \\
\text { (3) }\end{array}$ & $\begin{array}{c}\text { Slightly } \\
\text { Agree } \\
(4)\end{array}$ & $\begin{array}{c}\text { Agree } \\
(5)\end{array}$ & $\begin{array}{c}\text { Strongly } \\
\text { Agree } \\
(6)\end{array}$ & \\
\hline B7 & $\begin{array}{l}\text { it comes to safety. } \\
\text { I receive constructive suggestions if I work } \\
\text { unsafely. }\end{array}$ & 0 & 1 & 0 & 4 & 86 & 65 & 5.37 \\
\hline B8 & $\begin{array}{l}\text { Methods used to communicate safety information } \\
\text { are adequate. }\end{array}$ & 0 & 16 & 25 & 33 & 62 & 20 & 4.29 \\
\hline \multirow[t]{2}{*}{ B9 } & $\begin{array}{l}\text { My direct Supervisor discusses safety issues with } \\
\text { me. }\end{array}$ & 2 & 5 & 19 & 26 & 76 & 28 & 4.62 \\
\hline & & & & & & \multicolumn{2}{|c|}{ Average } & 4.87 \\
\hline $\mathbf{C}$ & Safety Rules and Procedures & & & & & & & \\
\hline $\mathrm{C} 1$ & Safety procedures are carefully allowed by all. & 0 & 0 & 1 & 25 & 82 & 48 & 5.13 \\
\hline $\mathrm{C} 2$ & Safety rules and procedures are easy to understand. & 0 & 5 & 27 & 37 & 69 & 18 & 4.44 \\
\hline $\mathrm{C} 3$ & Safety procedures are practical. & 0 & 3 & 22 & 25 & 79 & 27 & 4.67 \\
\hline $\mathrm{C} 4$ & $\begin{array}{l}\text { Safety procedures are not overlooked to meet } \\
\text { production targets. }\end{array}$ & 4 & 21 & 36 & 16 & 52 & 27 & 4.10 \\
\hline $\mathrm{C} 5$ & $\begin{array}{l}\text { All safety rules and procedures must be followed to } \\
\text { get the job done safely. }\end{array}$ & 0 & 2 & 7 & 14 & 59 & 74 & 5.26 \\
\hline C6 & $\begin{array}{l}\text { Safety requirements are not ignored to get a job } \\
\text { done. }\end{array}$ & 2 & 4 & 17 & 20 & 58 & 55 & 4.88 \\
\hline & & & & & & \multicolumn{2}{|c|}{ Average } & 4.75 \\
\hline $\mathbf{D}$ & Supportive Environment & & & & & & & \\
\hline D1 & $\begin{array}{l}\text { Employees are always encouraged to focus on } \\
\text { safety at their workplace. }\end{array}$ & 1 & 0 & 1 & 4 & 83 & 67 & 5.37 \\
\hline D2 & $\begin{array}{l}\text { My co-workers often give tips to each other on } \\
\text { how to work safely. }\end{array}$ & 0 & 4 & 2 & 27 & 94 & 29 & 4.91 \\
\hline D3 & $\begin{array}{l}\text { I am strongly encouraged to report unsafe } \\
\text { conditions in my workplace. }\end{array}$ & 0 & 2 & 9 & 10 & 90 & 45 & 5.07 \\
\hline D4 & $\begin{array}{l}\text { There are always enough people available to get } \\
\text { the job done safely. }\end{array}$ & 2 & 8 & 14 & 29 & 80 & 23 & 4.58 \\
\hline D5 & I receive praise for working safely. & 6 & 19 & 12 & 51 & 56 & 12 & 4.08 \\
\hline D6 & $\begin{array}{l}\text { No one criticizes me if I remind someone to work } \\
\text { safely. }\end{array}$ & 3 & 4 & 3 & 2 & 77 & 67 & 5.22 \\
\hline D7 & There is punishment for behaving unsafely. & 0 & 0 & 5 & 14 & 70 & 67 & 5.28 \\
\hline D8 & $\begin{array}{l}\text { My co-workers do care whether I am working } \\
\text { safely or not. }\end{array}$ & 0 & 0 & 3 & 20 & 81 & 52 & 5.17 \\
\hline D9 & $\begin{array}{l}\text { Employees who report safety issues are not } \\
\text { punished by their colleagues. }\end{array}$ & 2 & 3 & 18 & 29 & 78 & 26 & 4.64 \\
\hline D10 & $\begin{array}{l}\text { Workplace conditions support my ability to work } \\
\text { safely. }\end{array}$ & 3 & 16 & 17 & 24 & 71 & 25 & 4.40 \\
\hline D11 & I can work safely at my workplace. & 0 & 2 & 6 & 18 & 87 & 43 & 5.04 \\
\hline D12 & I gave enough time to get the job done safely. & 3 & 11 & 19 & 23 & 72 & 28 & 4.50 \\
\hline D13 & $\begin{array}{l}\text { I always get the tools or equipment I need to do } \\
\text { the job safely. }\end{array}$ & 0 & 12 & 18 & 21 & 76 & 29 & 4.59 \\
\hline D14 & Work targets align with safety measures. & 2 & 15 & 23 & 32 & 58 & 26 & 4.33 \\
\hline \multirow[t]{2}{*}{ D15 } & $\begin{array}{l}\text { My work environment reduces the possibility of } \\
\text { an accident. }\end{array}$ & 2 & 13 & 23 & 28 & 69 & 21 & 4.36 \\
\hline & & & & & & \multicolumn{2}{|c|}{ Average } & 4.77 \\
\hline \multirow[t]{2}{*}{$\mathbf{E}$} & Personal Safety Involvements and Needs & & & & & & & \\
\hline & Positive Statements & & & & & & & \\
\hline E1 & A safe place to work is very meaningful for me. & 0 & 0 & 0 & 0 & 32 & 124 & 5.79 \\
\hline E2 & $\begin{array}{l}\text { Safety is the number one priority for me when } \\
\text { completing a job. }\end{array}$ & 0 & 0 & 0 & 8 & 59 & 89 & 5.52 \\
\hline E3 & A continuing emphasis on safety is crucial for me. & 2 & 0 & 2 & 7 & 87 & 58 & 5.25 \\
\hline E4 & I understand all the safety rules. & 0 & 1 & 6 & 32 & 97 & 20 & 4.83 \\
\hline E5 & $\begin{array}{l}\text { I feel that my workplace has met the required } \\
\text { safety standards. }\end{array}$ & 0 & 1 & 8 & 16 & 96 & 35 & 5.00 \\
\hline E6 & $\begin{array}{l}\text { I am clear about my health and safety } \\
\text { responsibilities. }\end{array}$ & 0 & 0 & 3 & 22 & 94 & 37 & 5.06 \\
\hline E7 & I am involved in implementing safety at work. & 0 & 0 & 2 & 17 & 101 & 36 & 5.10 \\
\hline E8 & $\begin{array}{l}\text { I can influence safety performance in my } \\
\text { workplace. }\end{array}$ & 3 & 3 & 2 & 32 & 90 & 26 & 4.80 \\
\hline E9 & I report people who ignore safety procedures. & 0 & 1 & 2 & 7 & 70 & 76 & 5.40 \\
\hline E10 & I follow safety policy rather than simply doing & 3 & 8 & 7 & 20 & 79 & 39 & 4.80 \\
\hline
\end{tabular}




\begin{tabular}{|c|c|c|c|c|c|c|c|c|}
\hline \multirow[b]{2}{*}{ No } & \multirow[b]{2}{*}{ Item } & \multicolumn{6}{|c|}{ Frequency Distribution } & \multirow[b]{2}{*}{ Mean } \\
\hline & & $\begin{array}{c}\text { Strongly } \\
\text { Disagree } \\
(1) \\
\end{array}$ & $\begin{array}{c}\text { Disagree } \\
(2) \\
\end{array}$ & $\begin{array}{l}\text { Slightly } \\
\text { Disagree } \\
(3)\end{array}$ & $\begin{array}{c}\text { Slightly } \\
\text { Agree } \\
(4)\end{array}$ & $\begin{array}{c}\text { Agree } \\
(5)\end{array}$ & $\begin{array}{c}\text { Strongly } \\
\text { Agree } \\
(6)\end{array}$ & \\
\hline & $\begin{array}{l}\text { what I am told to do, e.g., to work quickly and } \\
\text { ignore safety. }\end{array}$ & & & & & & & \\
\hline E11 & $\begin{array}{l}\text { My responsibility is to work safely, including } \\
\text { reporting co-workers who do not work safely. }\end{array}$ & 4 & 13 & 9 & 18 & 68 & 44 & 4.70 \\
\hline E12 & It is unlikely that I will be involved in an accident. & 0 & 5 & 12 & 8 & 53 & 78 & 5.20 \\
\hline E13 & I am not worried about being injured on the job. & 16 & 42 & 15 & 17 & 49 & 17 & 3.59 \\
\hline \multirow[t]{3}{*}{ E14 } & $\begin{array}{l}\text { It is unlikely that I will have an accident in my } \\
\text { workplace. }\end{array}$ & 8 & 10 & 9 & 36 & 71 & 22 & 4.40 \\
\hline & & & & & & \multicolumn{2}{|c|}{ Average } & 4.95 \\
\hline & Safety Training & & & & & & & \\
\hline F1 & $\begin{array}{l}\text { I received adequate training to perform my job } \\
\text { safely. }\end{array}$ & 0 & 1 & 16 & 35 & 87 & 17 & 4.66 \\
\hline $\mathrm{F} 2$ & $\begin{array}{l}\text { Potential risks and consequences are identified in } \\
\text { safety training. }\end{array}$ & 0 & 1 & 9 & 29 & 87 & 30 & 4.87 \\
\hline F3 & The safety training provided is practical. & 0 & 0 & 3 & 19 & 100 & 34 & 5.06 \\
\hline F4 & $\begin{array}{l}\text { The company invests a lot of time and money in } \\
\text { safety training. }\end{array}$ & 1 & 5 & 23 & 47 & 59 & 21 & 4.42 \\
\hline \multirow[t]{3}{*}{ F5 } & $\begin{array}{l}\text { I am capable of identifying potentially hazardous } \\
\text { situations. }\end{array}$ & 0 & 0 & 4 & 28 & 106 & 18 & 4.88 \\
\hline & & & & & & \multicolumn{2}{|c|}{ Average } & 4.78 \\
\hline & & & & & & \multicolumn{2}{|c|}{ Total Average } & 4.89 \\
\hline
\end{tabular}

The Management Commitment dimension has a Mean value of 5.20. The average on the dimensions of commitment and concern for safety from the leader is at a score above $5.00 .13 .5 \%$ of respondents stated that they disagreed with statement A7 (My Plant Manager focuses on safety at all times, not only after accidents have occurred).

The Safety Communication dimension has a Mean value of 4.87. In general, Safety Communication in the company is at a score above 4.50 (agree level). However, on statement B8 (Methods used to communicate safety information are adequate) $26.3 \%$ of respondents stated that they disagree by giving statements that the safety communication method still needs improvement.

In the Safety Rules and Procedures dimension, the mean value is 4.75 , with $16.1 \%$ of respondents stating that they 'Slightly Disagree' to 'Strongly Disagree' because employees perceive the existing safety procedures as still quite challenging to understand and sometimes complicate the completion of tasks.

The survey results show that the Supportive Environment dimension has a Mean value of 4.77. In addition, as many as $86.9 \%$ of respondents stated that they agreed that their colleagues and work environment had helped them protect their safety.

The survey results on the Personal Safety Involvement and Needs dimension have a Mean value of 4.95 . In general, $91.0 \%$ of respondents agreed if the company always involves them in creating the workplace safe.

The survey results on the Safety Training dimension gave a Mean value of 4.78. Thus, $91.9 \%$ of respondents agreed that Safety Training has been going well. It is according to the needs in completing the job. 


\section{Discussion}

Employees' perceptions of the implementation of occupational safety in this company are at a reasonable level. The accident statistics in this company show that the number of days without work-related accidents (Lost Time Accident-Free Days) has reached 2767 days, while recorded work-related accidents (Total Recordable Injury Rate) is 0 (zero). That achievement has provided an accurate picture and strongly correlated with the Safety Climate in this company. References on best safety practices (related to the 6 Safety Climate dimensions used in this study) were collected for comparison and can be briefly summarized as follows.

Management commitment serves as a fundamental ground for exemplary implementation of the Occupational Safety system. Statement A5 that the Plant Manager has a total commitment to safety represents all the statements in this dimension. EHS (Environmental, Health, and Safety) Policy was made by management to expresses its vision and mission statements, commitment and determination to implement the policy, and the general EHS framework and work plan. It effectively marks the management's commitment to promoting, supporting, and driving sustainable EHS programs and eliminating injury cases.

The responses given to other statements in this dimension indicate that the employees agreed that their management and leadership show responsibility in ensuring their team members' safety. The responses are corroborated by the management's commitment to occupational safety, which can be seen from how they solve a safety issue and the extent of the management's measure to prevent safety events that may lead to a work-related accident and occupational disease. In addition, a Safety Inspection Program in all work areas has been implemented regularly by the management and leadership to improve awareness of workplace hazards and safety. As a result, the attitude of company leaders becomes role models and change agents to build a safety perspective.

Meanwhile, there are several respondents (13.5\%) who have the perception that the company leadership is only present when an accident has occurred. This condition was created by sharing information about accidents in other facilities through the corporate intranet. The leadership will identify risks to potential similar cases in this company's assets in the next step. Then this step creates the perception that the leadership seems to have just reacted to identify the same potential hazard after an accident occurs at the other facility.

According to Zohar ${ }^{20}$ in Lu's ${ }^{21}$ study, management commitment to Occupational Safety is the most determinant factor of a work-related accident control program, followed by Safety Officer's status in the organization, management-employees communication, and safety training. Management involvement in and commitment to good safety practices bring positive benefits to the organization, for example, lower incident rate and better safety attitude and behavior of the employees. ${ }^{22}$ The management's acute awareness of OHS, active participation in the Safety 
Committee, meticulous planning of safety aspects, and formulation of safety vision and mission are a basis that can direct an organization towards understanding work safety.

One factor affecting employees' perception of safety communication effectiveness is their perceived ability to talk to their leadership about safety issues. Employees' access to communication enables them to report unsafe situations more frequently and quickly. Effective communication also allows early prevention of potential accidents. ${ }^{23}$ Similarly, a study by Motter and Santos $^{24}$ suggests, various forms of safety communication at the workplace can be used effectively to improve employees' attentiveness at work. A good understanding of safe and unsafe behaviors will be nurtured among employees whose leader understands effective safety communication methods. ${ }^{25}$

Based on the survey results, statements B1 and B2 get the most 'Agree' responses. It is seen from the effect of safety information distributed through the visual communication boards accessible by the employees or sent using the company's email account to employees' mobile devices. The employees are also actively involved and encouraged to give their views and ideas for improvement through the 'People-Centered Safety' program. Direct interaction among employees and between employees and the management occurs. Safety information directly related to on-site work is discussed during each shift change and in every meeting at every level.

Besides it, the employees still considered it essential to improve safety information, as indicated by the statement B8 score. Therefore, one of the recommendations given was to maximize the use of electronic gadgets to update themselves with real-time information about safety issues at their workplace.

Some of the respondents working in the office area 'Disagree' on statement B9 that their direct Supervisor discussed safety issues with them. Their statement had to do with the fact that employees working in the office area rarely worked in areas, such as production and warehouse areas, where they could be exposed to direct physical hazards. The employees working in the office area suggested that toolbox meetings with thematic agendas be held as an improvement measure.

Safety rules in an organization can also be used to support coordination mechanisms and functions. ${ }^{26}$ Controlling safety risks through work procedures can minimize safety violations that can lead to work accidents. ${ }^{27}$ Safety rules and procedures must be formulated by taking into account any possible obstacle. The company always prioritizes direct observation and discussion process to obtain effective solutions. Safety rules and procedures are made not to make it difficult for employees to do their job and achieve business targets.

Based on the result about this dimension that the surveyed employees complied with the prevailing safety procedures and work standards. Their compliance results were generated by improving its employees' capabilities through safety standards and work procedure training. It is proven by increasing their awareness of the impacts and risks of their job. In addition, the company 
openly and consistently communicates about and upholds the prevailing disciplinary rules concerning the consequences of violating the general work safety rules.

Statement C4 needs to be addressed considering that some respondents chose 'Disagree'. Their disagreement with the statement on perceptions of safety procedures linked to production targets indicated dissenting views of and attitudes toward the prevailing rules. For some employees, safety rules only impeded performance target achievement. A recommendation suggested through the interviews was to get the employees more involved in integrating safety issues, particularly those related to technical aspects, into the company's work procedures.

Understanding factors that motivate employees to work safely is vital in eliminating unsafe behaviors and increase employees' participation in occupational safety activities. ${ }^{24}$ Support from the leadership and co-workers correlates positively with safety compliance. ${ }^{28,29}$ The company has its own 'Safety Values', one of which is to build interaction among employees to raise awareness of safety risks as the main factor in their way of thinking. A good reward and punishment model also helps shape a culture of awareness.

The company has enacted a safety obligation applicable to all employees, contract and outsourced workers, and visitors working within its area. The obligations require everyone to be aware of their own and others' safety and improve safety. All employees must protect each other's safety because safety is a condition necessary to all employees. Responsibility for safety rests not only on the EHS Department and Top Management. Building a strong foundation on safety values through promotional activities, annual safety programs, and the 'People-Centered Safety' program has encouraged close relationships between the company and employees, also employees and coworkers.

The employees and management are mutually well aware that a safe working location and environment contribute significantly to performance improvement. Safety is therefore placed as the top priority in the company's business operation. Such awareness is based on the understanding that occupational safety is everyone's right, which is why it is governed as a company regulation. It makes two statements that received the highest Mean scores in this dimension: statement E1 (5.79) and statement E2 (5.52). As the results show, $100 \%$ of the respondents answered 'Agree' and 'Strongly Agree'.

The respondents responded differently to statements E13 and E14. Respondents viewed that although they already had a safe workplace and related infrastructure (safety PPE, procedures, rules, and communication system) were available, the potential risks of work-related accidents remained a primary consideration by the employees and management. The employees' and the company's awareness of the importance of considering potential risks can be proven by the existence of a comprehensive risk mapping document managed sustainably through continuous risk assessment processes. 
Increasing employee involvement at the workplace can be done by engaging employees in safety management programs. ${ }^{30}$ In the company studied, employees' engagement in safety management programs is achieved as follows.

Representatives of employees at each level and the management are involved in the Occupational Health dan Safety Committee, as mandated by Regulation of the Minister of Manpower Number 4 of $1987 .^{31}$ The committee holds a monthly meeting to discuss safety performance, inspect all factory divisions to ensure safety, take corrective measures immediately upon identifying findings, and help design a recommended Occupational Health and Safety annual framework.

The company where the study was conducted also believes that occupational safety management should not be a passive activity. Instead, it should be developed and improved sustainably. Sustainable improvement should minimize or even eliminate work-related accident and occupational disease risks by engaging all the employees to seek solutions. The company has a routine program called safety kaizen, where all elements of workers and management contribute to the improvement of a safe workplace. Among the benefits of sustainable improvement are making employees more proactive and guiding them to understand that they play a crucial role in controlling their work environment. ${ }^{32}$

The safety feedback issue adopted in the company is also used as a tool for employees to offer suggestions directly. The company calls the scheme the "People-Centered Safety (PCS)" scheme. PCS scheme is outlined in a form that contains 4 (four) themes, namely safety control practice, awareness of hazard, work behavior and practice, and housekeeping. PCS scheme is designed so that the employees can remind one another about safety at work. The company also gives a reward for every PCS form turned in. A reward is given to motivate the employees to improve their performance and take better responsibility. ${ }^{33}$

A study shows that perception of safety climate influences safety performance through its effects on knowledge and motivation. ${ }^{34}$ The respondents' answer to statement F4 indicated that they wanted Safety Training to be conducted regularly and more frequently. They 'Agree' that the training provided by the company was applicable at their workplace. As reflected in the responses, it was believed that increasing safety training frequency would help improve employees' capability and maximize their performance. The company realized that personal safety competence is an essential foundation to support work and performance achievement in the company. Well-managed safety competence and training matrix by company and employees engaged in safety performance improvement are vital components for creating a good safety climate. A proper introduction to work hazards, risk management, and risk control constitute the core of the comprehensive safety training provided in the company. 
This study offers to contribute knowledge on how a company nurtures a good safety climate for its employees. The study can also be used to compare further studies on safety climate in manufacturing companies.

\section{Conclusion}

The study was conducted on a multinational manufacturing company that produces feminine care products. The study found the safety climate in this company was observed at a reasonable level demonstrated through:

The attitude of company leaders who have become role models and agents of change in building a safety perspective, as part of leadership commitment. The strong safety values that have succeeded in building interaction among employees to raise awareness of safety risks. Employee involvement at the workplace through engaging employees in safety committee, safety continuously improvement program and 'People-Centered Safety' program. Safety training programs have been well applied and suitable to support work needs.

Apart from these promising results, communication methods about safety need to be improved, including updating real-time information about safety and more extensive meeting. While another thing, the employees want to be more involved in preparing safety procedures to minimize the complexity in the job as a part of Safety Rules and Procedures dimension improvement.

\section{Conflict of Interest}

The authors declare that they have no conflict of interest.

\section{Acknowledgments}

The authors gratefully acknowledge the company's employees who participated in the survey and extended their appreciation to Rahardjo and Imat Riyana for the valuable discussions.

\section{Funding}

The authors state that they were not supported funding for this research.

\section{Reference}

1. World Health Organization. Reproductive Health Indicators: Guidelines for their generation, interpretation and analysis for global monitoring [Internet]. World Health Organization. Geneva: World Health Organization; 2006. 9 p. Available from: https://apps.who.int/iris/bitstream/handle/10665/43185/924156315X_eng.pdf

2. Badan Pusat Statistik. Penduduk Indonesia: Hasil Sensuk Penduduk 2010 [Internet]. 
Jakarta: Badan Pusat Statistik; 2013. 102 p. Available from: https://www.bps.go.id/publication/2013/03/05/becb3c0fa2dbec4af7a24430/pendudukindonesia-hasil-sp-2010.html

3. Badan Pusat Statistik. Hasil Sensus Penduduk 2020: Berita Resmi Statistik No. 7/01/Th. XXIV, 21 Januari 2021 [Internet]. Jakarta: Badan Pusat Statistik; 2021. 11 p. Available from: $\quad$ https://www.bps.go.id/pressrelease/2021/01/21/1854/hasil-sensus-penduduk2020.html\#

4. Qolbi N. KAO Indonesia kuasai 45\% pasar pembalut di Indonesia [Internet]. Kontan.co.id. 2018 [cited 2021 Jun 25]. Available from: https://industri.kontan.co.id/news/kao-indonesiakuasai-45-pasar-pembalut-di-indonesia

5. BPJS Ketenagakerjaan. Angka Kecelakaan Kerja Cenderung Meningkat, BPJS Ketenagakerjaan Bayar Santunan Rp1,2 Triliun [Internet]. BPJS Ketenagakerjaan. 2019 [cited 2021 Apr 6]. Available from: https://www.bpjsketenagakerjaan.go.id/berita/23322/Angka-Kecelakaan-Kerja-CenderungMeningkat,-BPJS-Ketenagakerjaan-Bayar-Santunan-Rp1,2-Triliun

6. Ridwan. Angka Kecelakaan Kerja Makin Meningkat, Industri Manufaktur Indonesia Didesak Segera Manfaatkan Otomatisasi [Internet]. industry.co.id. 2021 [cited 2021 Jun 7]. Available from: https://www.industry.co.id/read/81303/angka-kecelakaan-kerja-makinmeningkat-industri-manufaktur-indonesia-didesak-segera-manfaatkan-otomatisasi

7. ISafety Magazine. DICARI: Formula Jitu Penurun Angka Kecelakaan Kerja. ISafety Magazine Edisi Desember 2018: Rapor K3 Nasional 2018 Dalam Rangka Menyambut Bulan K3 [Internet]. 2018;14. Available from: https://katigaku.top/wpcontent/uploads/2019/01/ISI-LAYOUT-MAJALAH-ISAFETY-DIGITAL-01.pdf

8. Saptiyulda E. BPJS: Kematian akibat kecelakaan kerja terus meningkat [Internet]. antaranews.com. 2019 [cited 2021 Jun 8]. Available from: https://www.antaranews.com/berita/853247/bpjs-kematian-akibat-kecelakaan-kerja-terusmeningkat

9. Yoon SJ, Lin HK, Chen G, Yi S, Choi J, Rui Z. Effect of occupational health and safety management system on work-related accident rate and differences of occupational health and safety management system awareness between managers in South Korea's construction industry. Saf Health Work [Internet]. 2013;4(4):201-9. Available from: http://dx.doi.org/10.1016/j.shaw.2013.10.002

10. Republik Indonesia. Peraturan Pemerintah Republik Indonesia Nomor 50 Tahun 2012 tentang Penerapan Sistem Manajemen Keselamatan dan Kesehatan Kerja. Peraturan Pemerintah Indonesia; 2012 p. 32.

11. Kim Y, Park J, Park M. Creating a Culture of Prevention in Occupational Safety and Health 
Practice. Saf Health Work [Internet]. 2016;7(2):89-96. Available from: http://dx.doi.org/10.1016/j.shaw.2016.02.002

12. Step Change In Safety. Changing Minds. In: Changing Minds: A practical guide for behavioural change. 2003.

13. OGP. Shaping safety culture through safety leadership. 2013;(452):32. Available from: www.ogp.org.uk

14. Zou PXW, Sunindijo RY. Strategic Safety Management in Construction. Chichester: Wiley Blackwell; 2015.

15. Sunindijo RY, Loosemore M, Lestari F, Kusminanti Y, Widanarko B. Comparing safety climate in infrastructure and building projects in Indonesia. MATEC Web Conf [Internet]. 2019;258(International Conference on Sustainable Civil Engineering Structures and Construction Materials):7. Available from: https://doi.org/10.1051/matecconf/201925802024

16. Loosemore M, Sunindijo RY, Lestari F, Kusminanti Y, Widanarko B. Comparing the safety climate of the Indonesian and Australian construction industries: Cultural and institutional relativity in safety research. Eng Constr Archit Manag [Internet]. 2019;26(10):2206-22. Available from: https://doi.org/10.1108/ECAM-08-2018-0340

17. Lestari F, Sunindijo RY, Loosemore M, Kusminanti Y, Widanarko B. A safety climate framework for improving health and safety in the Indonesian construction industry. Int $\mathbf{J}$ Environ Res Public Health [Internet]. 2020;17(20):1-20. Available from: http://dx.doi.org/10.3390/ijerph17207462

18. Firdaus. Metodologi Penelitian Kuantitatif; Dilengkapi Analisis Regresi IBM SPSS Statistics Version 26.0. Bengkalis: DOTPLUS Publiser; 2021. 19 p.

19. Sekaran U, Bougie R. Research Methods for Business: A Skill Building Approach. Fifth Edit. Chichester: John Wiley \& Sons; 2010. 272 p.

20. Zohar D. Safety climate in industrial organizations: Theoretical and applied implications. J Appl Psychol [Internet]. 1980;65(1):96-102. Available from: https://doi.org/10.1037/00219010.65.1.96

21. Lu C, Yang C. Safety climate and safety behavior in the passenger ferry context. Elsevier [Internet]. 2011;43(Accid. Anal. Prev.):329-41. Available from: https://doi.org/10.1016/j.aap.2010.09.001

22. Michael JH, Evans DD, Jansen KJ, Haight JM. Management commitment to safety as organizational support: Relationships with non-safety outcomes in wood manufacturing employees. J Safety Res [Internet]. 2005;36(2):171-9. Available from: https://doi.org/10.1016/j.jsr.2005.03.002

23. Huang Y, Sinclair RR, Lee J, Mcfadden AC, Cheung JH, Murphy LA. Does talking the talk 
matter? E ff ects of supervisor safety communication and safety climate on long-haul truckers 'safety performance. Accid Anal Prev [Internet]. 2018;117(February):357-67. Available from: https://doi.org/10.1016/j.aap.2017.09.006

24. Motter AA, Santos M. The importance of communication for the maintenance of health and safety in work operations in ports. Saf Sci [Internet]. 2017;96:117-20. Available from: https://doi.org/10.1016/j.ssci.2017.03.020

25. Michael JH, George Z, Wiedenbeck JK, Ray CD. Production supervisor impacts on subordinates' safety outcomes: An investigation of leader-member exchange and safety communication. J Safety Res [Internet]. 2006;37:469-77. Available from: https://doi.org/10.1016/j.jsr.2006.06.004

26. Weichbrodt J. Safety rules as instruments for organizational control, coordination and knowledge: Implications for rules management. Saf Sci [Internet]. 2015;80:221-32. Available from: http://dx.doi.org/10.1016/j.ssci.2015.07.031

27. Kvalheim SA, Dahl Ø. Safety compliance and safety climate: A repeated cross-sectional study in the oil and gas industry. J Safety Res [Internet]. 2016;59:33-41. Available from: https://doi.org/10.1016/j.jsr.2016.10.006

28. Guo M, Liu S, Chu F, Ye L, Zhang Q. Supervisory and coworker support for safety: Buffers between job insecurity and safety performance of high-speed railway drivers in China. Saf Sci [Internet]. 2019;117(July 2018):290-8. Available from: https://doi.org/10.1016/j.ssci.2019.04.017

29. Brondino M, Silva SA, Pasini M. Multilevel approach to organizational and group safety climate and safety performance: Co-workers as the missing link. Saf Sci [Internet]. 2012;50(9):1847-56. Available from: http://dx.doi.org/10.1016/j.ssci.2012.04.010

30. Xue M, Al-Turjman F, Saravanan V. A labor safety performance and involvement of workers in accident reduction and prevention. Aggress Violent Behav [Internet]. 2021;(January). Available from: https://doi.org/10.1016/j.avb.2021.101560

31. Ministry of Manpower. PER.04/MEN/1987 Tentang Panitia Pembina Keselamatan dan Kesehatan Kerja Serta Tata Cara Penunjukan Ahli Keselamatan Kerja. Jakarta: Ministry Of Manpower; 1987 p. 1-7.

32. Manos A. The Benefits of Kaizen and Kaizen Events. Quality Progress [Internet]. 2007;40(2):47-8. Available from: https://www.proquest.com/openview/9d2fe051fa4889fcd7cfd18f6cae1d2b/1?pqorigsite $=$ gscholar\&cbl $=34671$

33. Febrianti S, Musadieq M Al, Prasetya A, Administrasi FI, Brawijaya U. Pengaruh Reward Dan Punishment Terhadap Motivasi Kerja Serta Dampaknya Terhadap Kinerja (Studi pada Karyawan PT . Panin Bank Tbk . Area Mikro Jombang). J Adm Bisnis [Internet]. 
2014;12(1):1-9.

Available

from:

http://administrasibisnis.studentjournal.ub.ac.id/index.php/jab/article/view/487

34. Neal A, Griffin MA, Hart PM. The impact of organizational climate on safety climate and individual behavior. Saf Sci [Internet]. 2000;34(1-3):99-109. Available from: https://doi.org/10.1016/S0925-7535(00)00008-4 